\title{
Dissolved organic matter contribution to rain water, throughfall and soil solution chemistry
}

\author{
N. Fillion ${ }^{1}$, A. Probst ${ }^{1,2}$ and J.L. Probst ${ }^{1,2, *}$ \\ ${ }^{1}$ École et Observatoire des Sciences de la Terre (EOST), Centre de Géochimie de la Surface, CNRS/Université Louis Pasteur, \\ UMR $n^{\circ}$ 7517, 1 rue Blessig, 67084 Strasbourg Cedex, France \\ ${ }^{2}$ Present address: Laboratoire des Mécanismes de Transfert en Géologie, CNRS/Université Paul Sabatier, UMR 5563, \\ 38 rue des trente-six ponts, 31400 Toulouse, France
}

\begin{abstract}
A method is proposed to determine the acidbase properties of natural water samples containing relatively high amounts of dissolved organic matter. The electroneutrality principle as well as titration data are used to estimate the organic anion concentration in open field precipitation, throughfall and soil solutions, and to develop empirical models based on $\mathrm{pH}$ and dissolved organic carbon content. The organic acids dissolved in throughfall have a similar acidic site density but are weaker than those dissolved in soil solution, stream and lake waters. This method is usefull to determine the contribution of organic anions to the charge balance and to the buffering capacity of dissolved organic rich waters with low acid neutralizing capacity. It can be used also to determine the respective contribution of natural organics and anthropogenic minerals to the total acidity of throughfall and rain waters.
\end{abstract}

Consequently, organic acids can significantly contribute to the buffering capacity and to the electrical balance of low Acid Neutralizing Capacity (ANC) and dissolved organic carbon (DOC) rich waters. One of the easiest ways to calculate organic anion concentrations in surface waters is to assume that the anionic deficit calculated on an electroneutrality basis is only due to organic anions [8,9]. Another approach based on chemical equilibrium calculations uses an organic acid model calibrated with potentiometric data [10]. Empirical relationships were also established for large-scale data base $[11,12]$. Such methods allow to estimate organic anion concentrations using only dissolved organic carbon (DOC) and $\mathrm{pH}$ measurements.

The main objectives of this study are (i) to investigate the acid-base properties of dissolved organic matter in throughfall and in soil solution of some representative forest stands in France; (ii) to develop empirical relationships between parameters such as $\mathrm{pH}$, dissolved organic carbon (DOC), organic matter contribution to acid neutralizing capacity (ANC), organic anion concentration and organic acidity; and (iii) to determine if the geographical situation, the climate, and the vegetation type influence the acid-base properties of the organic matter dissolved in throughfall.

\section{Material and methods}

The Acid Neutralizing Capacity (ANC) and $\mathrm{pH}$ are parameters commonly used to describe the acid-base status of surface waters, and more specifically, to characterize the degree of acidification and the sensibility of natural systems towards acid atmospheric deposition. However, organic and aluminium rich waters can be considered as exceptions for which Acid Neutralizing Capacity (ANC) and $\mathrm{pH}$ values are not sufficient to assess their acid-base properties [1,2]. Some areas in France such as the Vosges mountains are receiving substantial anthropogenic acidic deposition, particularly enhanced under spruce forests $[3,4]$. This may contribute, in sensitive areas, to the acidification of surface waters [5].

The natural organic matter is composed of a complex mixture of organic compounds, different in size, elemental composition and functionality [6]. Organic acids can represent more than $90 \%$ of dissolved organic matter present in surface waters, the remaining being carbohydrates, amino acids and hydrocarbons [6]. The carboxylic functional group is the most abundant acidic group. It is characterized by relatively high dissociation constants $\left(\mathrm{pK}_{\mathrm{a}} \sim 4\right)$ [7].
One of the objectives of the French permanent plot network for monitoring of forest ecosystems (REseau National de suivi à long terme des ECOsystèmes FORestiers: RENECOFOR) is to collect data in order to study the impact of atmospheric inputs on forest ecosystems. For that purpose, precipitation and soil solution were collected monthly since the end of 1992 at 27 sampling stations located all over France. The chemical data achieved over the period 19931995 [13] were used to select 7 stations to carry out this present study. The different types of atmospheric inputs (acidic, acidic and ammonia enriched, circumneutral with or without sea salt influence, and basic due to calcic dusts), as well as the vegetation species (beech, Norway spruce, maritime pine and white fir), were the two main selection criteria. Open field precipitation (47 samples), throughfall (65 samples) and soil solutions (23 samples at $20 \mathrm{~cm}$ and 28 samples at $70 \mathrm{~cm}$ depth) were collected from June 1996 to May 1997 at the selected stations. 
The samples were filtrated through $0.45 \mu \mathrm{m}$ celluloseacetate filters then kept at $5{ }^{\circ} \mathrm{C}$ until analysis. Major element concentrations were determined as followed: $\mathrm{Na}^{+}, \mathrm{K}^{+}, \mathrm{Ca}^{2+}$ and $\mathrm{Mg}^{2+}$ by flame atomic absorption spectrometry (Hitachi $\mathrm{Z}-8200), \mathrm{Cl}^{-}, \mathrm{NO}_{3}^{-}, \mathrm{SO}_{4}{ }^{2-}$ and $\mathrm{PO}_{4}{ }^{3-}$ by ionic chromatography (Dionex 4000i), $\mathrm{NH}_{4}^{+}$and $\mathrm{Si}(\mathrm{OH})_{4}$ by colorimetry (Technicon autoanalyser II). Trace elements such as Al, Fe and $\mathrm{Mn}$ were also measured using an inductively coupled plasma emission spectrometer (ARL 35000 c). pH was determined with a Mettler DL $40 \mathrm{pH}$-meter and a Mettler combined $\mathrm{pH}$ electrode (HA405-DXK), and conductivity with a Consort K 511 conductimeter. DOC was measured by catalysed combustion at $680{ }^{\circ} \mathrm{C}$ (Shimadzu TOC 5000) after acidification and gas purge. All samples were run in duplicates.

Titrations were developed in the laboratory [14] in order to quantify the organic acidity, using a Metrohm Titrino 716 titrator and an Orion Ross combined pH electrode. A $50 \mathrm{~mL}$ aliquot of sample was first titrated in a closed glass vessel with a strong acid $(\mathrm{HCl} 0.008 \mathrm{M})$ to $\mathrm{pH} \mathrm{3}$, and the Acid Neutralizing Capacity $\left(\mathrm{ANC}_{\mathrm{Gran}}\right)$ was determined using Gran's plot in the $\mathrm{pH}$ range of $3.0-4.0$. After 5-10 minutes of $\mathrm{N}_{2}$ bubbling, the sample was then back titrated with a strong base $(\mathrm{NaOH} 0.016 \mathrm{M})$ to $\mathrm{pH} 11$ under $\mathrm{N}_{2}$ with continuously degazing to avoid atmospheric carbon dioxide contamination). The weak acidity (Aci weak ) was calculated using again Gran's plots in the $\mathrm{pH}$ ranges of $3.0-3.5$ (strong acidity) and of $10.5-11.0$ (total acidity). The ionic strength of the sample were adjusted to $0.1 \mathrm{~N}$ with $\mathrm{KCl}$ then titrations were conducted at $25.0 \pm 0.1{ }^{\circ} \mathrm{C}$ to stabilize $\mathrm{pH}$ measurements thus improving Gran's plots (three replicates). Typically $\mathrm{ANC}_{\mathrm{Gran}}$ and $\mathrm{Aci}_{\text {weak }}$ uncertainties are 0 to $5 \mu \mathrm{eq} / \mathrm{L}$ and 0 to $25 \mu \mathrm{eq} / \mathrm{L}$, respectively. Blanks $(\mathrm{KCl} 0.1 \mathrm{~N}$ solutions) gave negligible values for $\mathrm{ANC}_{\mathrm{Gran}}$ and ranged from -20 to $+25 \mu \mathrm{eq} / \mathrm{L}$ for $\mathrm{Aci}_{\text {weak }}$.

\section{Results and discussion}

$\mathrm{pH}$, dissolved organic carbon (DOC), acid neutralizing capacity $\left(\mathrm{ANC}_{\mathrm{Gran}}\right), \mathrm{Al}, \mathrm{Fe}$ and $\mathrm{Mn}$ values of water are summarized in table I. The samples can be roughly classified into three categories: (i) open field precipitation and throughfall with less than $3 \mathrm{mg} / \mathrm{L}$ DOC and less than 5 $\mathrm{mmol} / \mathrm{L} \mathrm{Al}$; (ii) throughfall and basic soil solutions rich in $\operatorname{DOC}(>3 \mathrm{mg} / \mathrm{L})$ and poor in $\mathrm{Al}(<10 \mu \mathrm{mol} / \mathrm{L})$; and (iii) acidic soil solutions charaterized by relatively high $\mathrm{Al}$ concentration $(5-80 \mu \mathrm{mol} / \mathrm{L})$ and by moderate DOC content $(<7.5 \mathrm{mg} / \mathrm{L})$.

Two different approaches are described to measure the organic anion concentration in open field precipitation and in throughfall. The first one is based on charge balance calculations and the second one on equilibrium models using titration data.

\section{The charge balance method}

The charge balance (CB) of samples containing low concentration of $\mathrm{Al}$ can be expressed as following, using a proton reference level of 2 for $\mathrm{Al}$ [1]:

$$
\begin{aligned}
\mathrm{CB} & =\left[\mathrm{Na}^{+}\right]+\left[\mathrm{K}^{+}\right]+2\left[\mathrm{Mg}^{2+}\right]+2\left[\mathrm{Ca}^{2+}\right]+\left[\mathrm{NH}_{4}^{+}\right] \\
& +2\left[\mathrm{Mn}^{2+}\right]+2\left[\mathrm{Al}^{2+}\right]+\left[\mathrm{H}^{+}\right] \\
& -\left[\mathrm{Cl}^{-}\right]-\left[\mathrm{NO}^{3-}\right]-2\left[\mathrm{SO}_{4}{ }^{2-}\right]-\left[\mathrm{PO}_{4}{ }^{3-}\right] \\
& -\left(\mathrm{ANC}_{\mathrm{Gran}}+\left[\mathrm{H}^{+}\right]\right) .
\end{aligned}
$$

Nonetheless, this charge balance does not reflect the exact organic anion concentration of the sample because some organic anions are included in the term $\mathrm{ANC}_{\mathrm{Gran}}+\left[\mathrm{H}^{+}\right]$. In other words, $\mathrm{CB}$ represents the fraction of organic anions which is not titrated with a strong acid. Therefore, in order to estimate the organic contribution to $\mathrm{ANC}_{\mathrm{Gran}}$, it was postulated that the deviation of the $\mathrm{ANC}_{\mathrm{Gran}}$ from a reference value $\left(\mathrm{ANC}_{\mathrm{o}}\right)$ can be attributed to organic anions, the aluminium contribution to $\mathrm{ANC}_{\mathrm{Gran}}$ being negligeable. $\mathrm{ANC}_{\mathrm{o}}$ is defined for aquatic systems containing only bicarbonate and carbonate anions as basic buffering species. French streams $[15,16]$ and precipitation (this study) with less than $3 \mathrm{mg} / \mathrm{L}$ DOC were used to develop an empirical equation (see also Fig. 1):

$$
\begin{aligned}
\mathrm{ANC}_{\mathrm{o}}(\mathrm{meq} / \mathrm{L}) & =10^{3}\left(0.004210^{-8.33} /\left(10^{-8.33}+10^{-\mathrm{pH}}\right)\right. \\
& \left.-10^{-\mathrm{pH}}+10^{-14+\mathrm{pH}}\right)
\end{aligned}
$$

An estimation of the organic contribution to the $\mathrm{ANC}_{\mathrm{Gran}}$

\begin{tabular}{|c|c|c|c|c|c|c|}
\hline Water type & $p H$ & $D O C(\mathrm{mg} / \mathrm{L}$ of $\mathrm{C})$ & $A N C_{\text {Gran }}(m e q / L)$ & $A l(\mu \mathrm{mol} / \mathrm{L})$ & $F e(\mu \mathrm{mol} / L)$ & $M n(\mu \mathrm{mol} / L)$ \\
\hline Open field precipitation & $4.3-6.7$ & $0.4-3.8$ & $-0.039-0.127$ & - & - & - \\
\hline Throughfall & $3.8-6.6$ & $0.5-51.5$ & $-0.182-0.291$ & $0-10$ & $0-1$ & $0-41$ \\
\hline Soil solution $(20 \mathrm{~cm})$ & $4.5-6.7$ & $0.9-10.4$ & $-0.006-0.104$ & $0-79$ & $0-1$ & $0-10$ \\
\hline Soil solution $(70 \mathrm{~cm})$ & $4.6-7.0$ & $0.4-3.6$ & $0.005-0.166$ & $0-72$ & $0-1$ & $0-6$ \\
\hline
\end{tabular}
$\left(\mathrm{ORG}_{\mathrm{ANC}}\right)$ is then:

$$
\mathrm{ORG}_{\mathrm{ANC}}=\mathrm{ANC}_{\mathrm{Gran}}-\mathrm{ANC}_{\mathrm{o}}
$$

Table I. Minimum and maximum values of some chemical parameters for the different water samples. DOC: dissolved organic carbon, ANC $_{\text {Gran }}$ : Acid Neutralizing Capacity determined by strong acid titration and using Gran's plot. 


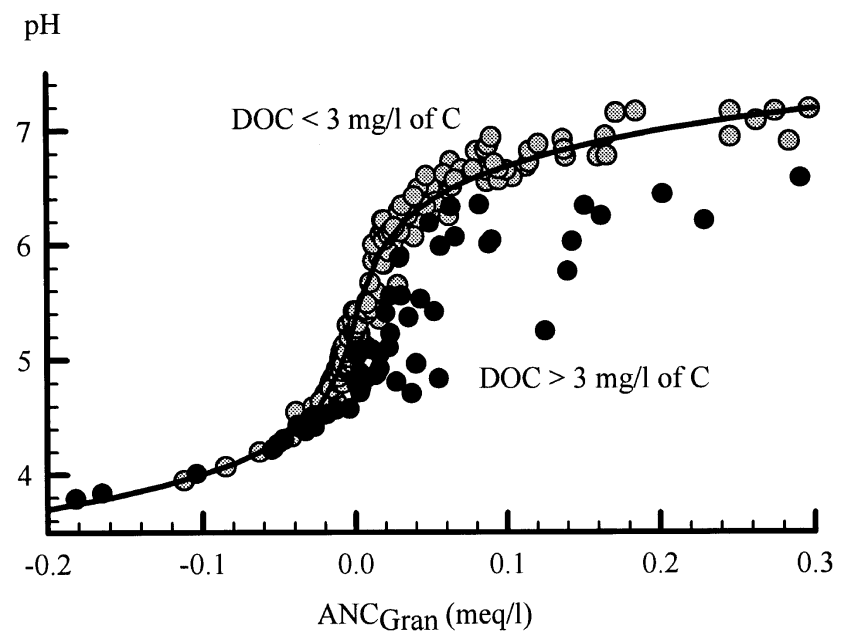

Figure 1. $\mathrm{pH}$ versus Acid Neutralizing Capacity $\left(\mathrm{ANC}_{\mathrm{Gran}}\right)$ for samples containing less (stream [13,14], spring and precipitation) or more (throughfall) than $3 \mathrm{mg} / \mathrm{L}$ of dissolved organic carbon (DOC). The simulated curve represents the reference value $\mathrm{ANC}_{\circ}$ (see in the text Eq. (2)) calculated for DOC $<3 \mathrm{mg} / \mathrm{L}$ samples.

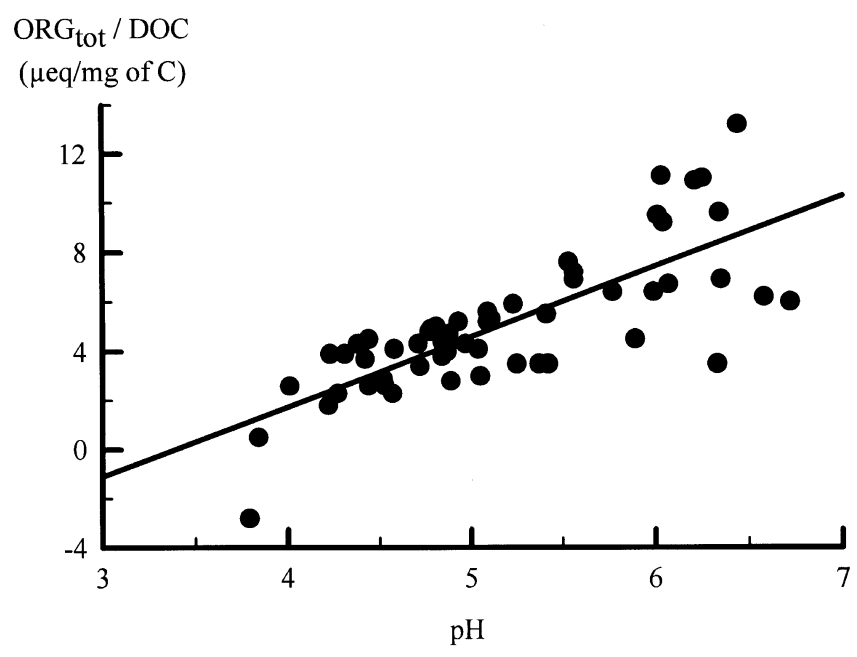

Figure 3. Charge density $\left(\mathrm{ORG}_{\mathrm{tot}} / \mathrm{DOC}\right)$ versus $\mathrm{pH}$ for throughfall containing more than $3 \mathrm{mg} / \mathrm{L}$ of dissolved organic carbon (DOC).

The difference between the organic contribution to $\mathrm{ANC}_{\mathrm{Gran}}$ and the reference value for the waters containing a few amount of organic carbon $(<3 \mathrm{mg} / \mathrm{L})$ is less than $10 \mu \mathrm{eq} / \mathrm{L}$ in the $\mathrm{pH}$ range of $4.0-6.6$. It is following a Gaussian type distribution. The organic anion concentration $\left(\mathrm{ORG}_{\mathrm{tot}}\right)$ can finally be calculated as:

$$
\mathrm{ORG}_{\mathrm{tot}}=\mathrm{CB}+\mathrm{ORG}_{\mathrm{ANC}}
$$

The organic anion concentration depends greatly upon both $\mathrm{pH}$ and dissolved organic carbon parameters. This is illus-

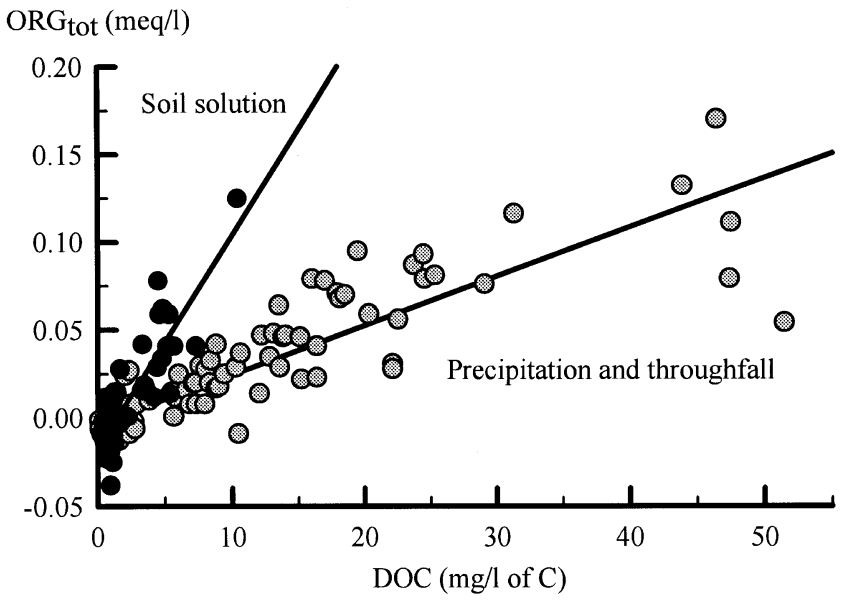

Figure 2. Organic anion concentration $\left(O R G_{t o t}\right)$ versus dissolved organic carbon (DOC) content for precipitation, throughfall and soil solution.

trated by the linear relationships of $\mathrm{ORG}_{\text {tot }}$ versus $\mathrm{DOC}$ (Fig. 2) and of the charge density $\left(\mathrm{ORG}_{\mathrm{tot}} / \mathrm{DOC}\right)$ versus $\mathrm{pH}$ (Fig. 3). Moreover, the organic anion concentration in soil solutions is higher than in throughfall, even though soil solutions are more acidic. An empirical model based on a multiple regression analysis can be established for open field precipitation and throughfall:

$$
\begin{aligned}
\mathrm{ORG}_{\text {tot }}(\mathrm{meq} / \mathrm{L}) & =5.2510^{-3} \mathrm{DOC}(\mathrm{mg} / \mathrm{L} \text { of } \mathrm{C}) \\
& +2.3510^{-2} \mathrm{pH}-0.127
\end{aligned}
$$

with $r^{2}=0.79$ for $n=116$ water samples.

Consequently, the factors influencing the $\mathrm{pH}$ and the dissolved organic carbon (DOC) content of throughfall have an effect on organic anion chemistry. These factors include the temperature (hot in summer/cold in winter), the vegetation type (coniferous/deciduous trees), the rainfall amount as well as temporal variation (storm/long term events), and the nature of the atmospheric inputs (basic/acidic).

\section{Organic anion concentration: The equilibrium model method}

The organic acidity $\left(C_{\mathrm{ORG}}\right)$ of open field precipitation and of throughfall samples was deduced from the weak acidity $\left(\right.$ Aci $\left._{\text {weak }}\right)$ measured by basic titration, after correction for the blank and the weak inorganic acidity induced by the presence of ammonia, silica and phosphate. For that purpose, thermodynamic equilibrium constants adjusted to $0.1 \mathrm{~N} \mathrm{KCl}$ medium were used [17]. Initial and final $\mathrm{pH}$ values of the basic titration are 3 and 11 respectively, which correspond to correction factors of 0.98 for ammonia, 0.97 for silica and 1.30 for phosphate. Thus the measured organic acidity is:

$$
\begin{aligned}
C_{\mathrm{ORG}} & =\mathrm{Aci}_{\text {weak }}-0.98\left[\mathrm{NH}_{4}^{+}\right]-0.97\left[\mathrm{H}_{4} \mathrm{SiO}_{4}\right] \\
& -1.30\left[\mathrm{PO}_{4}^{3-}\right]-\text { blank }
\end{aligned}
$$


However, the organic acidity measured by titration $\left(C_{\mathrm{ORG}}\right)$ represents only a fraction of the total organic acidity $\left(C_{\mathrm{ORG} \text { tot }}\right)$, because of the presence of dissociated organic anions even in acidic media (corresponding to the quantity $\mathrm{CB})$. Thus, the total organic acidity is:

$$
C_{\mathrm{ORG} \text { tot }}=C_{\mathrm{ORG}}+\mathrm{CB} \text {. }
$$

The acid dissociation constant $\left(K_{\mathrm{a}}\right)$ of the organic acids is calculated using a monoprotic acid dissociation model for all samples containing more than $3 \mathrm{mg} / \mathrm{L}$ of dissolved organic carbon (DOC):

$$
K_{\mathrm{a}}=\left[\mathrm{H}^{+}\right] \mathrm{ORG}_{\mathrm{tot}} /\left(C_{\mathrm{ORG} \text { tot }}-\mathrm{ORG}_{\mathrm{tot}}\right)
$$

The results show that the organic acids are weaker in throughfall than in soil solutions. Moreover, a linear relationship between the $\mathrm{pK}_{\mathrm{a}}\left(-\log K_{\mathrm{a}}\right)$ and the $\mathrm{pH}$ of the throughfall samples is observed:

$$
\mathrm{pK}_{\mathrm{a}}=0.48 \mathrm{pH}+2.61
$$

with $r^{2}=0.4$ for $n=52$ water samples.

This equation can then be used to estimate the organic anion concentration in throughfall containing more than $3 \mathrm{mg} / \mathrm{L}$ of dissolved organic carbon (DOC):

$$
\begin{aligned}
\mathrm{ORG}_{\text {tot }}(\mathrm{meq} / \mathrm{L})= & 9.710^{-3} \mathrm{DOC}(\mathrm{mg} / \mathrm{L} \text { of } \mathrm{C}) / \\
& \left(1+10^{-0.52 \mathrm{pH}+2.61}\right)
\end{aligned}
$$

If the different organic anion concentrations estimated from both charge balance (Eq. 5) and equilibrium model (Eq. 10) methods are compared, it appears that the equilibrium model method gives results closer to the organic anion concentrations calculated using equation (4) than the charge balance method with an underestimation of only $7 \%$ versus $20 \%$.

\section{Comparison of DOC acid-base properties}

The dissolved organic matter acid-base characteristics for throughfall and soil solutions are summarized in table II. Data from the literature obtained on lake and stream and soil solution samples from different geographic regions are also mentioned for comparison [2,8,10,11,18-24].

The site densities of all types of water are very similar. This means that the organic acidity is only affected by parameters influencing the amount of dissolved organic carbon (DOC) in surface waters. However, the acid dissociation constants reveal a discrepancy between throughfall and other types of surface waters. The organic contribution to the ANC is not so different from values obtained for many studies in the literature. On the other hand, the organic contribution to the charge balance is about half of what can be measured in lake and stream water samples. Thus, it is obvious that the proportion of organic acids having low pKa values are less represented in throughfall than in soil solutions, in lakes and in streams. Moreover, this fraction of strong organic acids could be considered as the fingerprint of organic matter in surface waters. Indeed, organic acids titrated with either a strong acid or a strong base have the same acid-base properties. Consequently, it is important to use both the charge balance and titration data to characterize the organic acids dissolved in surface waters.

\section{Conclusion}

This study allowed to investigate the acid-base properties of dissolved organic matter in open field precipitation, throughfall and in soil solution of some representative forest stands in France. An empirical modelling based on $\mathrm{pH}$ and dissolved organic carbon (DOC) can be proposed to predict the contribution of dissolved organic matter (organic anion concentration and organic acidity) to the charge balance and to the buffering capacity (acid neutralizing capacity, ANC) of organic rich natural precipitations. Nevertheless, the acidbase properties of dissolved organics vary according to the different type of waters (throughfall, soil solution, river and lake).

Empirical models (5) and (10) developped to estimate the

\begin{tabular}{|c|c|c|c|c|c|}
\hline Acid-base parameters & Formula & $\begin{array}{l}\text { Throughfall } \\
\text { (this study) }\end{array}$ & $\begin{array}{l}\text { Soil solution } \\
\text { (this study) }\end{array}$ & $\begin{array}{l}\text { Lakes, streams } \\
\text { (literature) }\end{array}$ & $\begin{array}{l}\text { Soil solutions } \\
\text { (literature) }\end{array}$ \\
\hline Organic contribution to ANC & $\mathrm{ORG}_{\mathrm{ANC}} / \mathrm{DOC}$ & $2.3 \pm 2.2$ & - & $1.6-2.7$ & - \\
\hline $\begin{array}{l}\text { Organic contribution } \\
\text { to the charge balance }\end{array}$ & CB/DOC & $2.8 \pm 1.2$ & $8.4 \pm 4.3$ & $4.5-5.5$ & - \\
\hline Charge density & $\mathrm{ORG}_{\mathrm{tot}} / \mathrm{DOC}$ & $5.1 \pm 2.8$ & $8.4 \pm 4.3$ & $7-8$ & - \\
\hline Site density & $\left(C_{\mathrm{ORG} \text { tot }}\right) / \mathrm{DOC}$ & $9.7 \pm 1.7$ & $13.0 \pm 3.8$ & $10(7.5-13.5)$ & $10(7.5-13.5)$ \\
\hline Acid dissociation constant & $\mathrm{pK}_{\mathrm{a}}$ & $5.1 \pm 0.5$ & $4.8 \pm 0.6$ & $4-4.5$ & $4-4.5$ \\
\hline
\end{tabular}
organic anion concentration can be used to evaluate organic

Table II. Acid-base properties of dissolved organic matter (Unit: $\mu \mathrm{eq} / \mathrm{mg}$ of C). ANC: Acid Neutralizing Capacity, DOC: Dissolved Organic Carbon, CB: charge balance, ORGtot: organic anion concentration, $C_{\mathrm{ORG}}$ tot: total organic acidity, $\mathrm{pKa}=-\log K_{\mathrm{a}}$ : acid dissociation constant. Literature: see references $[2,8,10,11,18-24]$. 
acidity versus mineral acidity in throughfall [25] collected at 7 selected stations of the network for monitoring of forest ecosystems (RENECOFOR network: REseau National de suivi à long terme des ECOsystèmes FORestiers). Such a method is therefore useful to predict the influence of the organic inputs to the chemical behavior of throughfall and soil solution, using easily measurable parameters such as $\mathrm{pH}$ and dissolved organic carbon (DOC). It would be particularly interesting to use this method to study organic rich river waters ("Coca Cola" rivers) which play an important role in the transfer of metals and to assess the relative importance of anthropogenic mineral acidity inputs to forest soils in the context of acid atmospheric pollution.

\section{Acknowledgements}

This study was performed in collaboration with the National French Forest Office and we would like to thank particularly E. Ulrich and the technical staff. It received a financial support from the European Community (DG IV) research program (contract nb 96.60.FR.004.0).

\section{References}

1. Sullivan, T. J.; Driscoll, C. T.; Gherini, S. A.; Munson, R. K.; Cook, R. B.; Charles, D. F.; Yatsko, C. P. Nature 1989, 338, 408-410.

2. Hemond, H. F. Environ. Sci. Technol. 1990, 24, 1486-1489.

3. Probst, A.; Viville, D.; Fritz, B.; Ambroise, B.; Dambrine, E. Water Air Soil Pollut. 1992, 62, 337-347.

4. Probst, A.; Lelong, F.; Viville, D.; Durand, P.; Ambroise, B.; Fritz, B. In: Landmann, G.; Bonneau, M. Eds., Springer Verlag (NY), 1995a; pp 203-225.

5. Probst, A.; Probst, J. L.; Massabuau, J. C.; Fritz, B. In: Landmann, G.; Bonneau, M. Eds., Springer Verlag (NY), 1995b; pp 371-386.
6. Thurman, E. M. Organic geochemistry of natural waters, Dordrecht, Martinus Nijhoff/Dr W Junk Publishers, 1985.

7. Perdue, E. M.; Reuter, J. H.; Parrish, R. S. Geochim. Cosmochim. Acta 1984, 48, 1257-1263.

8. Driscoll, C. T.; Fuller, R. D.; Schecher, W. D. Water Air Soil Pollut. 1989, 43, 21-40.

9. Probst, J. L.; Nkounkou, R. R.; Krempp, G.; Bricquet, J. P.; Thiébaux, J. P.; Olivry, J. C. J. Hydrol. 1992, 135, 237-257.

10. Oliver, B. G.; Thurman, E. M.; Malcolm, R. L. Geochim. Cosmochim. Acta 1983, 47, 2031-2035.

11. Wilkinson, K. J.; Jones, H. G.; Cambell, P. G. C.; Lachance, M. Water Air Soil Pollut. 1992, 61, 57-74.

12. Kortelainen, P. Publ. Water Env. Res. Inst. Finland 1993, 13, $1-48$.

13. Ulrich, E.; Lanier, M.; Schneider, A. ONF-Département des Recherches Techniques 1995.

14. Fillion, N. PhD thesis, Université Louis Pasteur, Strasbourg, 1998; p 244

15. Party, J. P.; Probst, A.; Dambrine, E. Rapport scientifique ADEME année 1992, 1993; p 68.

16. Février, C.; Party, J. P.; Probst, A. C.R. Acad. Sci. Paris 1999, 328, 29-35.

17. Stumm, W.; Morgan, J. J. Aquatic Chem., J. Wiley \& Sons, 1996.

18. Cantrell, K. J.; Serbiz, S. M.; Perdue, E. M. Geochim. Cosmochim. Acta 1990, 54, 1247-1254.

19. Vance, G. F.; David, M. B. Geochim. Cosmochim. Acta 1991, 55, 3611-3625.

20. Kortelainen, P.; David, M. B.; Roila, T.; Mäkinen, I. Environ. Int. 1992, 18, 621-629.

21. Jehlicka, J.; Rouiller, J.; Guillet, B.; Dambrine, E. Proceeding of the 11th International Meeting of the Humic Substances Society Bari, 1992; pp 81-86.

22. Munson, R. K.; Gherini, S. A. Wat. Resour. Res. 1993, 29 , 891-899.

23. Mattsson, T.; Kortelainen, P.; David, M.B. Water Air and Soil Pollut. 1995, 85, 505-510.

24. Hruska, J.; Johnson, C. E.; Kram, P. Wat. Resour. Res. 1996, 32, 2841-2851.

25. Fillion, N.; Probst, A.; Probst, J. L. C.R. Acad. Sci. Paris 1999, 328, 333-339. 